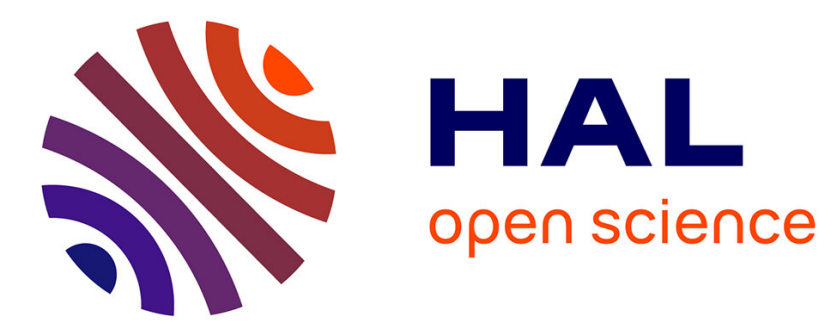

\title{
Prostitution in nightclubs in border areas of the Czech Republic
}

\author{
Mathilde Darley
}

\section{To cite this version:}

Mathilde Darley. Prostitution in nightclubs in border areas of the Czech Republic. Revue française de sociologie, 2009, 50 (Supplement), pp.95-124. halshs-00648863

\section{HAL Id: halshs-00648863 \\ https://shs.hal.science/halshs-00648863}

Submitted on 30 Aug 2021

HAL is a multi-disciplinary open access archive for the deposit and dissemination of scientific research documents, whether they are published or not. The documents may come from teaching and research institutions in France or abroad, or from public or private research centers.
L'archive ouverte pluridisciplinaire HAL, est destinée au dépôt et à la diffusion de documents scientifiques de niveau recherche, publiés ou non, émanant des établissements d'enseignement et de recherche français ou étrangers, des laboratoires publics ou privés. 


\title{
Prostitution in Nightclubs in Border Areas of the Czech Republic*
}

\begin{abstract}
Spaces of prostitution first appeared in Czech Republic border areas when the country's borders were opened, and they are primarily aimed at a German-speaking clientele. They represent an excellent field for studying the social and spatial configurations associated with the sale of sexual services. They are also an occasion for reconsidering questions of how sociology can gain access to a "difficult" field and how to interview actors linked to the activity of prostitution. Analysis of the prostitution trajectories of women and customers in these border-area nightclubs brings to light the complex, multiform power relations that develop in them; it also reveals the great fantasy-generating potential of the social fact of prostitution. Prostitution on the borders of the Czech Republic seems interpretable as a confined space where fantasies and affirmations of identity become crystallized.
\end{abstract}

Prostitution, defined here as "the fact of establishing relations with other people that logically culminate in a sexual act with the purpose of obtaining payment in the short term" (Brochier, 2005), appeared in border areas of the Czech Republic in the early 1990s, shortly after the fall of the communist regime and the opening of the country's borders. The sex market here was produced by the economic differential between the Czech Republic and its west European neighbors; it has developed mainly on the borders with Germany and Austria and is aimed primarily at a German-speaking clientele. The trucking routes between the Czech Republic and Germany and Austria have often been described as "sex roads", even "slave markets". (1) On the Czech side, the phenomenon seems to have long been socially taboo and out of bounds for legitimate research. A report published by the German NGO KARO just before the Czech Republic officially joined the European Union and indicating the presence of a fully developed child prostitution market aimed at German customers in the city of Cheb (Schauer, 2003), on the border with Germany did, however, trigger sharp debate around the issue of sex tourism in Czech border areas. In response to heavy media coverage of the

* My thanks to Gilles Faveral-Garrigues, Christian Lequesne and Lilian Mathieu, also to the anonymous reading committee of the RFS for their attentive rereading and precious comments on earlier versions of this article.
(1) See, for example, Florian Klenk, "Prostitution: der moderne Sklavenmarkt. Erkundungen im deutsch-tschechischen Grenzgebiet", Die Zeit, 40 (Sept. 9, 2006). 
phenomenon, Czech and German authorities issued statements relativizing the extent of sexual exploitation of children in the Czech Republic and presenting police cooperation between the two countries as the main response to the "problem". However, the legal void around prostitution activities in the Czech Republic (2) and persistent obstacles to transnational police cooperation limit the influence the police institution can have on the development of the sex trade in border areas. Despite regular publication of alarmist articles in the Czech, German and Austrian press presenting the tragic fate of prostitutes, particularly migrants, and the omnipresence of prostitution in the lives of border populations, it seems that authorities on both side of the border are trying to ignore the phenomenon, and there are very few studies of the marketing of sexual services on the Czech-German and Czech-Austrian borders. Nonetheless, the world of border area prostitution in the Czech Republic is inscribed in a particular geographical and social space, which I will try to present here. The fall of the communist regime, the complex, conflictual history of the country's borders until 1993, its entry into the European Union in 2004 and the simplification of border controls that ensued all constitute the context in which prostitution appeared and developed in the Czech border landscape; the border here is the institution that has made certain forms of sex trade on the edges of the Czech Republic possible, due to the juxtaposition of low wages and limited opportunities for low-skilled persons (migrant populations in particular) on one side of the border and comparatively well-off, readily accessible customers on the other (Donnan and Wilson, 1999, p. 92).

The analysis presented here, the outcome of research done in 2005 and 2006 on prostitution in what are called "nightclubs" in the border regions of Šumava (near the Czech-Bavarian border) and Moravia (near the CzechAustrian border), studies the relations between different prostitution actors, particularly prostitutes and customers, from the perspective of the spatial inscription of those relations on the border between countries of different economic levels and contrasted political histories. I first shed light on the geographic and socio-economic context of border prostitution in the Czech Republic, so as to relate prostitution organization to the conditions that make it possible and its territorial manifestations. After defining the research object and contextualizing the research field, I return to the methodological procedure I used to apprehend a field traditionally termed "difficult". Given how little research there is on the power relations among actors in the world of

(2) Though not formally permitted, prostitution is not prohibited in the Czech Republic. While Czech law forbids the opening of prostitution businesses, this prohibition is readily circumvented by having the business officially registered as a "pension" or "nightclub". A bill aimed at regulating prostitution was drafted by the former Czech interior minister Frantisek Bublan in August 2005. It forbids prostitution of minors under 18 and makes it compulsory for registered prostitutes to undergo regular medical examinations and pay taxes. It also increases local jurisdiction; towns can decide what zones prostitution can be practiced in and prohibit it systematically in the vicinity of schools and youth organizations. Towns in the border regions of the Czech Republic were quite active in drafting the bill, but the majority of Christian-Democrats and Conservatives are strongly opposed to it. 
prostitution, I then try to present the representations and trajectories of border prostitution actors, namely customers and prostitutes, and the power games that characterize their relationships. On the basis of this sociological study of actors, the prostitution world can be understood as a "social construct" (Howe, 2006) and the border areas in which prostitution is practiced as symbolic spaces for affirming and reaffirming representations of identity.

\section{Geographic and social characteristics of the border area prostitution spaces}

The border areas studied are in western and southern Czech Republic (3) and are characterized above all by a strong concentration of "nightclubs" in a relatively small area. The term "nightclub" is a euphemized name for places of prostitution in the Czech border regions. The number of such clubs rose from 25 in 1997 to more than 70 today on the Czech-Bavarian border alone (a border measuring 150 kilometers), ${ }^{(4)}$ though this border is much less exposed than the country's northwestern one. The places of prostitution are thus integral parts of the landscape; in some places they even dominate it, as in certain villages where the main street is lined with erotic clubs. But to understand the actors' representations and strategies, it is important to resituate the forms of what I will call prostitutional sexuality on the Czech border zones in the particular historical, geographic and social context they developed in.

\section{Border-opening and prostitution}

Border area prostitution appeared soon after the borders of Czechoslovakia (which later became the Czech Republic) were opened, and it quite clearly seems to have arisen from the sharp economic differential between the German and Austrian border regions and the corresponding Czech regions. Though certain NGOs active in the regions today note a slight increase in the presence of Czech men in the night clubs, Czechs still account for only a tiny proportion of prostitution service consumers in the border zones; the vast majority are German and Austrian. The fact that German and Austrian customers go to the Czech Republic for sexual services cannot be explained by German and Austrian law, because while prostitution is generally considered a gray area of Czech legislation, it is permitted and regulated in both Germany and Austria. Sexual service supply is non-existent in the German and Austrian border areas due to restrictions on opening places of prostitution

(3) The research this text is based on was done primarily in Folmava and Železná Ruda, on the Czech-German border, and Znojmo, on the Czech-Austrian border.
(4) Interview with representatives of a health protection organization working with prostitutes in the border region of Plzen (Czech-Bavarian border). 
in rural zones, ${ }^{(5)}$ but these measures appear to have been conceived first and foremost as a means of preventing the Czech clubs from expanding to the other side of the border; they are therefore more an effect than a cause of prostitution in the $\mathrm{Czech}$ border areas. Prices for prostitution services in the clubs situated in the Czech Republic are generally one-half to one-third those practiced in the neighboring countries, and this combined with the availability of other goods and services (gas, cigarettes, restaurants, etc.) in the same areas and likewise at lower prices seem the two main factors explaining the fact that the majority of the clientele are German-speaking. (6)

The heavy marketing materials developed by the owners of the prostitution clubs in this highly competitive environment are therefore almost entirely in German and use "classic" market arguments to tout the wares. On the CzechAustrian border, for example, immense billboards inform visitors that they can get "sex today for 39€" (Sex heute um 39€), while at the club entrances there are posters announcing "fresh girls today" or a supply " $100 \%$ Czech". In addition to these marketing tools, commonly used in "distribution networks", the tone chosen by club owners to describe border area prostitution often reflects a representation of the world of prostitution in terms of a "market," a place where supply of and demand for sexual services can intersect. This is attested by the metaphor used by a manager to justify his refusal to let me question customers on the parking lot of his club: "It's like at the supermarket, you can't take up a position at the entrance and tell the customers that what's waiting for them inside is no good." (7) Competition here is not only around service prices but also service content. In the border areas, there is greater marketing of erotic services designed to precede or follow the sexual act itself, such as suggestive shows or dances; the quality of this material seems to constitute an important marketing argument for the customers I questioned. ${ }^{(8)}$ To these business motivations should be added the guarantee of anonymity that for German and Austrian customers seems implied by the fact of crossing a state border.

Clearly, there is a more subjective dimension to using crosssborder prostitution services, a dimension often inherent in sex tourism and that consists in constructing other cultures -in this case what are called "eastern-European

(5) See the prostitution law passed by the German parliament in December 2001 and effective January 1, 2002 (Gesetz, zur Regelung der Rechtsverhältnisse der ProstituiertenProst $G)$.

(6) Jana, an NGO working to prevent the spread of sexually transmitted diseases (STDs) among prostitutes on the Czech-Bavarian border, estimates that 2,000 German men cross the western Czech Republic border daily to consume sexual services in the prostitution clubs (this does not include street prostitution). See Rolan Kirbach, "Die Rückkehr zum Leichtsinn”, Die Zeit, 49 (Nov. 11, 2004).
(7) Words of a club owner, Czech-Austrian border.

(8) Noted on the website of one of the main clubs in the Znojmo region on the CzechAustrian border: "Unfortunately, most places calling themselves nightclubs are no bigger than 20 square meters and they are deadly dull. Having a good time in one of these clubs may amount to nothing more than watching television. Fortunately, there are also nightclubs deserving of the name and that make the city they are located in more attractive. In our region, club X [name altered] is the very best place of this sort -and that's no exaggeration". 
cultures"- as "different with regard to sexual practices and mores" (Bishop and Robinson, 1998, p. 114). Indeed, one particularity of the world of prostitution in border area nightclubs is the overrepresentation of prostitutes from the former socialist republics, (9) particularly Ukraine and neighboring Slovakia, but also Russia, Belarus, Moldavia, Romania and Bulgaria. The presence of foreign prostitutes is also clearly due to an economic differential, this time between the Czech Republic and those prostitutes' native countries. These foreign prostitutes are generally depicted as victims of criminal organizations profiting from prostitution practiced by migrant women, or as dissolute "foreigners" willing to do anything for money, but their motivations and itineraries as prostitutes have actually not been studied much. In a context where the focus is primarily on trafficking in women ${ }^{(10)}$ and in which prostitution is historically assimilated to this trade (see Corbin, 1978, pp. 405-406), the way migrant prostitutes are perceived depends on the analytic scale. At the international scale, energies are concentrated on combating trafficking in women and the tone is one of legitimate indignation; the understanding is that migrant prostitutes are "victims", and this is supported by citing particularly grim cases of trafficking, covered extensively by the press, together with alarmist estimates. (11) Local actors, on the other hand, are more likely to point an accusing finger at the women migrants who prostitute themselves (Redoutey, 2005), as attested by certain declarations made by local police, residents and tourists in villages where prostitution is a major activity.

\section{The territories of border area prostitution}

The places studied here are not given over exclusively to prostitution; on the contrary, they exhibit cyclical types of territorialization. There are strong variations between their daytime/nighttime and weekday/weekend uses. However, the territorial manifestations of the cyclical character of the prostitution activity differ from those observed in other contexts, such as the urban landscape of Rio de Janeiro (Botelho de Mattos and Angelo Campos Ribeiro, 1997). During summer days, most of the people in the town of Železná Ruda, in the mountainous Šumava region of southwestern Czech Republic, are tourist hikers, and in winter they are skiers, while Moravia, in the south, is

(9) According to Jana estimates, nearly two-thirds of prostitutes working on the CzechBavarian border are from the former socialist states. See papers from a conference entitled "AIDS und Prostitution in des erweiterten Union, altes Thema - neue Wege", held by Jana in Plzeň in October 2004.

(10) See the international instruments recently adopted to combat trafficking in women, namely the Protocol to Prevent, Suppress and Punish Trafficking in Persons, Especially Women and Children, passed by the United Nations General Assembly on
November 15, 2000 and signed in December 2000 in Palermo; also the July 2002 European Union Council Framework Decision on combating trafficking in human beings.

(11) For an example, see declarations by Detlef Uben, head of the human trafficking department of the Hamburg criminal bureau. Uben, quoted by Florian Klenk ("Prostitution: der moderne Sklavenmarkt. Erkundungen im deutsch-tschechischen Grenzgebiet, Die Zeit, $40,28 / 09 / 2006$, p. 4) estimates that $95 \%$ of prostitutes are forced into practicing the activity. 
reputed for its winegrowing and is trying to promote green tourism. The Czech border areas also have immense Vietnamese markets specialized in counterfeit goods (see below) and much appreciated by the German and Austrian border populations. Moreover, certain structures developed in the last ten years on the Czech side of the border, such as the enormous shopping center Excalibur City with its stores, "wellness" and animal grooming centers, child care facilities, gas stations and daily bus service to and from Vienna, have further enriched the supply of leisure and tourism activities for Germanspeaking neighbors in the Czech border areas. More classically, casinos have been opened; these are associated almost systematically with prostitution operations; many customers start their evening at the casino and then move on to a nightclub. The geographic position of the border area prostitution operations, i.e., on major highways linking Dresden and Prague in the north, Plzeň and Munich or Salzburg in the southwest, and Prague and Vienna in the south, has also worked in favor of the current overlapping of tourist, business and prostitution activities in Czech border areas.

Though street prostitution is widespread along the border segments of these major highways, I have chosen to focus in this study on prostitution in nightclubs, for two reasons. First, if I had studied street prostitution I would not have been able to approach customers as systematically as I did, since customers using the services of prostitutes standing on the side of these transnational highways do not usually get out of their vehicles. Second, the street prostitution milieu is said to be more difficult to penetrate for being controlled by specific groups, often family groups, often Roma; they keep the prostitutes working for them under strict surveillance. ${ }^{(12)}$ Moreover, there is less street prostitution in the regions I studied than in the border zones of northwest Czech Republic with its Highway E55, now known for its image as an openair sex market. The hypotheses presented in this article thus do not apply to all border area prostitution in the Czech Republic; specific studies of street prostitution and prostitution in the northwestern border areas of the country should be done.

On the basis of interviews and visits to the places of prostitution, it seems possible to identify a sort of "prostitution geography" (Redoutey, 2005) that takes into account the location of the clubs as well as their size and volume of activity. Whereas there is a strong concentration of clubs along the main street of Železná Ruda, a town on the border with Bavaria, the clubs in the region of Znojmo, located on the Czech-Austrian border, are scattered over several kilometers in the vicinity of that town. This differentiated spread seems to influence prostitutes' lifestyles and work styles to some degree, and their relationship to the local population. Prostitutes living and working in Železná Ruda clubs are known to local inhabitants, merchants and taxi drivers, who spontaneously indicate the bar they gather in in the afternoons, when activity is slow. The fact that these women are not anonymous may constitute a form

(12) This observation is also made by NGOs working with prostitutes, who sometimes have difficulty approaching street prostitutes. 
of security for them. On the other hand, because clubs in the Moravian region of Znojmo are relatively isolated, women working there may be dependent on club managers, e.g., to drive them into town to do shopping and errands.

Furthermore, places of prostitution exhibit size characteristics, and therefore levels of activity, that vary greatly both from city to city and club to club. The best-known places are generally big; they employ approximately 40 women, reputed to be very beautiful, and the way the rooms are laid out attests to "professional" marketing of sexual services, with red interiors, dance floors, colored lights and such facilities as swimming pools and jacuzzis. In these clubs several girls in underclothes cluster around the customer when he enters, and it seems as though the designers have tried to create an atmosphere conducive to the consumption of sexual services. But there are also much smaller clubs, employing a smaller number of prostitutes -the smallest have only two or three women. Their interiors resemble either a rundown bar or a private house.

\section{The ways prostitutes and customers meet up and the actors involved in that encounter}

The four prostitutes working in a small club on the Czech-German border indicated to me that they had an average of 120 customers per weekend while for the rest of the week they had around 60, thus confirming the broad gap I observed in the field between the relative calm of weekdays and the hyperactivity of the weekend. My observations in and around the clubs, combined with my interviews of prostitutes and customers, brought to light that men visiting the prostitution establishments could be "passive" customers -this is the term I will use for men who come to the clubs more or less regularly but do not necessarily use the sexual services for sale there. This way of visiting places of prostitution may be a first stage in becoming an "active" customer -i.e., consuming sexual services- or an enduring way of using places of prostitution; in the latter case, those places are envisioned more as a place to "go watch" what goes on or to meet women, establish contact, flirt.

When sexual services are performed, this happens in bedrooms; these are both the prostitutes' private spaces (they live in the clubs, frequently sharing the room with a colleague) and their place of work. In contrast to German and Austrian clubs, which display clear price regulations for number of minutes spent with the prostitute and delimit services (striptease and vaginal intercourse, for example), the price for "a time" is usually determined in terms of time spent and not services rendered. NGOs stress that this type of billing is very attractive to German and Austrian customers: women working in clubs in Czech border areas, particularly foreigners, seem to have difficulty limiting the sexual services their partners can demand; customers therefore think they are "allowed to do anything they want". (13)

(13) Interview with representatives of a health protection organization working with prostitutes on the Czech-Bavarian border. 
The fee negotiated for the room is usually around 30 to $40 €$ for a halfhour, and the services for which there is the greatest demand seem to be fellatio, which customers say they cannot get from their customary partners, and vaginal intercourse. In answer to demand from younger customers, certain clubs have established special rates for "quick" sexual services, billed 20 to $30 €$ for a quarter of an hour. ${ }^{(14)}$ Means of payment vary from one club to another. At some, customers pay the manager at the bar; at others they pay the prostitute directly, who then hands over part of the money to the manager. Customer payment can be divided between manager and prostitute in one of two ways. The bigger clubs usually choose to have their prostitutes pay a fixed amount, by the day or month, to cover their housing expenses; once they have paid the "rent", they can keep all the money they get from the customers, but they still have to pay for their food and the drinks at the bar that are part of their activity -these are usually quite high-priced. (15) The smaller clubs also seem to prefer this financial arrangement because it guarantees the clubowner regular takings. Medium-sized clubs, on the other hand, seem to favor a system of "free" lodging; in exchange, the prostitutes hand over $50 \%$ of their earnings to the owner. In both these arrangements, prostitutes hand over approximately half of their earnings. Ukrainian prostitutes may also have to turn over part of their earnings to the procurer who arranged their trip to the Czech Republic and their job at the club. The procurer in turn has special relations with certain clubs, which he supplies with women and gravitates around, generally demanding that the prostitute turn over $25 \%$ of her earnings to reimburse him, he says, for the money he spent getting her a visa and organizing the trip. Ukrainian prostitutes therefore usually only manage to keep around a fourth of what they make.

Club owners are difficult to study. But a long interview with an owner who had come as a customer to one of the clubs I studied, and certain statements collected from prostitutes and customers, together with direct observation of some clubs and information from non-governmental actors furnished me with some information. If we are to believe the police and NGO members, most of the official club-owners are of Czech nationality, namely because of Czech legal restrictions on property acquisition by foreigners, but they work cooperatively with German or Austrian partners. Though few owners would tolerate the presence of researchers on their parking lots -some even reacted violently and threatened me when I asked for permission to talk to people around their club- most accept regular visits from NGOs accredited to check the health of the women working in the clubs, especially to see if there are STD problems. The presence of "healthy girls" is important for the image of the clubs. Managers often say they prefer Czech and Slovak girls to "foreigners", particularly Ukrainians, who they say consume too much alcohol. (16) Many of them develop their marketing instruments on the basis of racist prejudices

(14) Information gathered from prostitutes working on the Czech-German border.

(15) Interviews with prostitutes working in clubs on the Czech-German border.
(16) Interview with members of an NGO working to help prostitutes on the CzechGerman border. 
holding that "eastern European women" -and first among them Czechs- are more beautiful, "fresh", less arrogant and more fond of sex than western European women. These culturalist stereotypes often go together with gendered representations of social roles, the understanding being that "prostitution is the best work a woman can get if she wants to earn money" -this is also what explains why it is the "the world's oldest profession". (17) A young owner interviewed at the Czech-German border stated: "If a woman has no problem with it, she'd be a fool not to take up this work. In any case, women never have free relations with men. When they've got a boyfriend, he has to pay for their apartment or car or else he's no longer interesting to them. So there's nothing surprising in the fact that women decide to charge money for their bodies." This owner also described the main border area clubs as very professional, meaning that they respected hygiene norms and carefully selected the women they allowed to work in their clubs. The atmosphere in them was "calm and relaxed", he said, and the women were "all doing this willingly". Police inspections are relatively unlikely, and the owners seem to have good relations with the police officers, ${ }^{(18)}$ who for their part say "there is no problem". (19)

Lastly, though I do not discuss meetings with street prostitutes here since it has not been possible to study that research object in detail, certain aspects of it may be mentioned in order to give a sense of the particularities of the different forms of border area prostitution. Though much more developed on the northwestern border of the Czech Republic (northern Bohemia), street prostitution is also present, though marginally, in the Šumava and Moravia regions studied here. It involves almost exclusively Czech women (Šumava) and Romani women (Moravia) and is generally described by local NGO actors as more dangerous for the prostitutes, who are more likely to be subject to police raids -this is easier for the police because the women are practicing out of doors and are therefore more visible and accessible to them- and attacks by both customers and racketeering "gangs" preying on prostitutes. (20) The prostitutes I interviewed also seem to rank prostitution activity types, putting street prostitution at the bottom of the ladder because of the generally lower price rates and the more difficult working conditions, as well as the presence of women forced into prostitution because of drug addiction, for example.

\section{Interviewing prostitution actors: customers and prostitutes}

The lines of thinking followed in this article arose from interviews with different actors in prostitution operations and the world of prostitution,

(17) Excerpts from an interview with a German club-owner on the Czech-German border.

(18) Police officers are sometimes accused of having close ties with prostitution club owners. See declarations gathered from officers in the organized crime unit at Plzeň and Brno.

(19) Interview with a city police officer on the Czech-German border.

(20) Problem mentioned by organizations working to help prostitutes in border areas. 
namely German-speaking prostitution customers in the Czech border areas and prostitutes working in the clubs, representatives of the NGOs doing social work with the prostitutes in the border areas, police officers, and inhabitants of villages considered centers of prostitution. The emphasis is on prostitution customers and their relation with the prostituted woman, and, less systematically, the prostitutes themselves. As indicated above, the club owners and managers were encountered only marginally, either when I went to ask permission to do research in the clubs or when I approached some of them as customers on club parking lots.

\section{“Getting customers to talk"}

The diversity of the actors questioned naturally led me to adapt the methodology used to the different types of respondents. While it proved fairly easy to gather information from local residents -this generally took the form of informal conversations with employees of the hotels, bars and restaurants in the region and persons living in the immediate vicinity of prostitution operations- collecting information from customers is known to be difficult, which explains why there are as yet very few studies bearing specifically on consumers of sexual services. I chose to take up this area of research without defining any particular methodology, on the one hand because of the extremely divided opinions found in the literature about the "best way to approach customers" and on the other the sense that to come into this field reputed to be "difficult" with a whole set of methodological precepts was to run the risk of confining the research object, categorizing it as "difficult" without first personally experiencing it as such.

I first chose to approach customers in the immediate vicinity of the places of prostitution and at peak hours; i.e., at night, and preferably on the weekend. ${ }^{(21)}$ In fact, my first attempts were made in the daytime in Czech border area gas stations (where Germans and Austrians residing on the other side of the border regularly come to fill their tanks at prices below those charged in German and Austrian gas stations), and they were often met with indignant reluctance to speak of sex on "neutral territory" from men used to practicing "transborder shopping". These first interviews thus enabled me to observe the importance of establishing a distinction between two worlds: the daytime world of potentially family expeditions to the Vietnamese bazaars on the other side of the border (and trips to the gas station and cigarette distributors), and the nighttime world, potentially given over to sex tourism.

(21) For the purposes of this study, approximately 25 German-speaking customers were interviewed, in German, for between 10 and 90 minutes. The interviews were conducted over four stays in the border regions, each lasting three to five days. Because of the material conditions in which the interviews were done (at night on parking lots), they could not be recorded, nor could I simultaneously take notes. The information collected was organized afterward into an ethnographic notebook, with succinct remarks noted immediately after each interview and more detailed information added after each series of interviews. 
So as not to make the men I questioned ill at ease, I tried to present my study in relatively neutral, even naive terms, as academic research bearing on border regions in general, in the course of which it had become clear to me that the nightclubs occupied a prominent position in the border area landscape. Without presupposing that the persons questioned had come there for sex with prostitutes, even though I had seen them enter and leave a club, I preferred to ask them first if "by chance" they knew what went on there, possibly through hearsay. My first, exploratory interviews had began with questions about what respondents knew about the prostitution milieu there, and this had revealed my interlocutors' tendency to interpret the very mention of the word "prostitution" as a personal accusation of possibly stigmatized sexual practices. The reactions I collected were almost entirely indignant, and could even amount to a categorical refusal to say anything on the matter. It was on the basis of this first experience that I became aware of the necessity to banish from my discourse any phrasing that could suggest that my interlocutors were there to consume sexual services, leaving it up to them to reveal their role as active prostitution customers if they wished. And from the start of the interview on, I asked questions not about the customers themselves and their sexual practices, but the women working in the clubs, in order to give a less "confessional" dimension to the information being supplied by the men questioned. Taking up the question of prostitution by way of prostitutes offered the advantage of leaving the respondents the permanent option of presenting information and impressions as "second-hand" if they wished, and thereby of preserving the feeling of protecting their privacy (even though the detailed character of the information supplied often attested to highly accurate knowledge of the prostitution world that could surely not have been acquired through information received second-hand). I considered "customers" all men questioned on the parking lots as they entered or left the club. Though many of them stated they did not consume sexual services, the relatively extensive knowledge they seemed to have about how the place operated and the regularity of their visits led me to consider their accounts as "customer" accounts.

Discovering by trial and error that it was a good idea to raise the question of the prostitutes as a means of approaching the customers also enabled me to set vibrating in customers a "heroic chord": they could mention the role of rescuer (of a woman forced to prostitute herself) that they might be led to play in the prostitution game. I will return further on to the importance of this heroic dimension in the discourse of prostitution customers, but for the time being let me just mention that using it in order to establish contact with the customers seems to have allowed me to distinguish myself immediately in the eyes of the customers from any totalizing, moralistic discourse. It was particularly important to let the customer know quickly that my discourse was removed from the generally admitted perception of customers as misogynous given that the researcher was of the female sex and thus ran the risk of being identified a priori by the persons being questioned with one of the various feminist lobbies who condemn men's use of prostitutional sex. (22) I thus

(22) See for example the report of the Coalition Against Trafficking in Women (CATW), available on http://www.catwinternational.org/factbook/czech.php. 
sought to emphasize my effort to be neutral and the fact that I had no preconceived opinion on the question; to do this I stressed the conditional and impersonal nature of the questions whenever possible. The circumstances in which the interviews were conducted -at night in the parking lots of places of prostitution; i.e., in a "border-space" between the privacy of the clubs and the anonymity of the public space that begins just outside the bounds of the parking lot- also helped to prevent a power relation from developing between researcher and respondent, since both found themselves in an uncertain border area that is usually understood to be risky to penetrate for both parties. However, it is important to keep in mind that because I was only able to interview customers willing to talk, I probably did not meet customers considered dangerous by the prostitutes themselves or, if I did meet some, they were careful to keep quiet about behaviors that they know are damaging to the physical or psychological integrity of the prostituted person. The hypotheses presented here therefore do not claim in any way to be representative, as this is illusory for any study of prostitution customers, but result instead from information collected in the course of ethnographic observation of the prostitutional territories and the actors studied.

I at first feared that customers would refuse to speak of their prostitutional sexuality with a female interlocutor who was in some cases younger than they. Still, it seems that the researcher's age and sex were finally not an obstacle to collecting customer confidences, and may even in some cases have represented a resource: ${ }^{(23)}$ whereas being close to their age encouraged younger respondents to answer in a tone of generational closeness, older respondents often treated me with a form of paternalism that was further stimulated by the deliberate naivety of the questions.

\section{Exchanges with the prostitutes}

Most of the interviews with prostitutes working in the clubs ${ }^{(24)}$ took place near but not in the clubs (in public spaces such as busstops, etc.) and during slack hours, namely on weekday afternoons, when customers were few and far between. Certain conversations took place in clubs I was permitted to enter, clubs where the activity was slow enough to enable me to speak to both the occasional customers and the prostitutes. ${ }^{(25)}$

(23) Other surveys of prostitution customers also mention their declared preference for being interviewed by a female interviewer; they say they can confide more easily in a woman. See Bouamama (2004, p. 154).

(24) I conducted only six interviews with prostitutes for the purposes of this study since the focus here is on the customer-prostitute relation. The interviews lasted between two and three hours and the information collected was confirmed and in some cases supplemented by interviews with local police and NGO representatives working with prostitutes.
(25) In outdoor interviews, the contact was established relatively informally with a group of prostitutes sunning themselves at a busstop. I wanted to maintain the informal tone of the interview by not recording it. I did take notes during the exchanges, however, and completed them afterwards. Interviews done in clubs were of course not recorded or noted down at the time given the presence of potential customers; rather, I recorded the information in my notebook just after leaving the club, as I had done after customer interviews. 
Contact with the women working in the clubs seems to have been facilitated by the fact that the researcher was female and close to their age. The slight age difference did make it nearly inevitable that the prostitutes would compare their situation with the researcher's. And though it would be vain to try to deny that such a comparison often encouraged the prostitute to perceive her own lot negatively, it seems to me that it also allowed for identifying certain strategies on the prostitutes' part of resisting against the stigma that accompanies the exercise of their activities. Interviews conducted outside the clubs were extremely open and informal; they were with a group of prostitutes whose curiosity had been awakened by my presence in the village. To satisfy that curiosity, I was careful to allow the women interviewed to ask me as many questions as they liked. These questions pertained primarily to the researcher's age and personal and professional trajectory, and the answers given were often first elicited by the effect of the comparison mentioned above, the first reaction by the prostitutes being to devalue their own experience. This negative, resigned view of their own condition was quickly followed by verbal and behavioral attempts at valorizing some aspects of their activity or the skills it required. I discuss these strategies in greater detail further on; I generally understand them as vectors of "stigma resistance", and they were particularly likely to emerge given that the interviews took place outdoors and without any time-space constraint for the respondents (who went back and forth between the club and the space I had invested) and given that the conversation emphasized customer-prostitute relations. Indeed, this aspect of their activity, often deliberately avoided by NGOs in contact with prostitutes, seems to me to make it possible to call into question certain stereotyped representations of the power relations obtaining in the world of prostitution.

\section{Prostitutional trajectories}

The information collected from the various actors reveals a game of influence and power that is more complex than what is generally suggested by studies of prostitution. To shed light on this complexity, I will try to present the practices and discourses that accompany the customers' and prostitutes' experience of the prostitution world.

\section{Customers: losers or perverts?}

The fascination that prostitutes generally have for writers (Siegmund, 2006) and researchers tends to leave their customers in shadow (Hoigard and Finstad, 1992). The lack of empirical data on customers' practices and their prostitution-related representations is often justified by citing the difficulty of questioning this group of actors, and this in turn leads to perceiving customers as a homogeneous group whose sexual behavior is deviant and marginal. The 
interviews I had with female representatives of NGOs seeking to help prostitutes reveal that the actors directly implicated in this prostitution field are not immune to certain vague fears and the general feeling that people have that it is preferable to keep their distance and protect themselves from men who consume sexual services (Howe, 2004). Seeking to account for what appears a nebulous, ill-known presence, certain sociologists have sought to develop a typology of customers and their motivations, grouping them into categories (Månsson, 2006) which generally distinguish between customers sexually attracted to the image of "the whore"; those who seek types of sexuality in prostitution that they do not have access to with their usual sexual partners; those for whom sex with prostitutes is the only possible form of sexuality; men who see the sexual act as a physical necessity justifying certain consumption practices and for whom prostitution presents the advantage of not requiring any emotional investment (Prieur and Taksdal, 1993), and lastly, customers nostalgic for the old order, where men dominated women (WelzerLang, Barbosa and Mathieu, 1994, p. 195). This set of categories, established by various authors for different national contexts (France and Sweden, for example), is the one Saïd Bouamama (2004) used in distinguishing his four types of customers: sexually or emotionally isolated persons; persons who are not aligned with the value of equality (seeking an image of women as submissive); merchandise buyers; and men allergic to commitment and responsibility. Other typologies are based on sexual consumption habits rather than customer motivations and distinguish occasional customers from regular ones, and, in this second category, customers who have relations with other women from customers who live alone (Mossuz-Lavau, 2005).

In the discourses I collected from customers, certain elements understood to underlie these categorizations may be identified. Still, the authority that these established typologies seem to enjoy -they structure most studies of prostitution customers- may lead to choosing, out of all the information that customers communicate, only information that corroborates the categories considered legitimate, and this reduces the field of possibility in analysis of the motivations and practices of prostitutional sexuality. I do not seek to confirm a pre-established typology, but only to describe certain discursive means of rationalizing a type of sexuality that is generally considered deviant, without claiming to be exhaustive. On the one hand, discourse analysis runs the risk of neglecting certain power techniques operative in the mechanisms of prostitution use, because it focuses attention on the speaker; on the other, the material collected in interviews with customers, whatever the sample size, cannot be considered representative because it is impossible to interview some customers. ${ }^{(26)}$

In the border areas of the Czech Republic, having recourse to prostitutional sexuality is generally interpreted by men who claim to be non-customers, by

(26) Unless otherwise indicated, the quotations in this section are excerpted from interviews with German-speaking prostitution 
local populations and even by the prostitutes themselves, as will be seen, as a sign of belonging to the category of "loser" in both the economic game and the game of love. Consumers of sex market services are assumed to be unemployed persons living off German or Austrian welfare payments who "have to pay for what others get for free"; (27) i.e., a sexual partner. Up against the moralizing judgments generally made of their sexual habits, Austrian and German prostitution customers in border area nightclubs develop a variety of discursive strategies, ranging from denial to heroicizing their sexual practices to trying to clear themselves.

Most customers have internalized the stigma inherent in prostitutional sexuality and begin by denying any implication in the prostitution world, even though they are being interviewed upon entering or leaving the clubs and even though the regularity of their visits has been attested -by the parking-lot guard, for example. The arguments they put forward to persuade the researcher that they do not belong to the customer "group" attest to their own perception of this form of sexuality as negative and deviant. One of the first reflexes is to try to resituate their sexual and amorous behavior immediately within "normality" or what is generally perceived as such, by means of arguments apparently considered automatically "exculpating", including "I'm not a customer, I've got a girlfriend." (28) To make it clear to the interlocutor that there is a divide between themselves and the deviant world of prostitutional sexuality, some men also refuse to continue the interview on the subject. But in most cases, the men questioned were willing to express their impressions of the prostitution world, after clearly indicating to the researcher that they were not of that world. Having devoted their first sentences in the interview to establishing their non-customer status and justifying their presence at places of prostitution by saying that the casino is nearby, that they are waiting for a friend, or that they are there out of curiosity, "regulars" who define themselves as non-customers then agree to tell "what I've heard". The account and impressions are often so detailed that it is not really likely that they were transmitted by hearsay, though "the regular" regularly recalls that he is only presenting second-hand information. He may be conscious of the researcher's capacity for discernment, but the value and plausibility of his claim does not really matter: his statement establishes a necessary symbolic break between two statuses, that of customer and that of non-customer, an indispensable ritual before there can be any exchange about prostitutional sexuality.

Other customers make no bones about their sexual habits, but seek to infuse them with an "ethical" dimension. This is the case of men who declare that they consider it a point of honor to have relations only with "willing" prostitutes who "take pleasure in the sex act". While most customers confess their inability to distinguish between prostitutes forced to work and so-called "willing" prostitutes, ${ }^{(29)}$ and say they think that the motivation of women who

(27) Words of a man who defined himself as a non-customer.

(28) Response by several men upon entering or leaving the club.
(29) I would insist on the necessarily subjective nature of such notions as "consent", "willing prostitution", and "forced prostitution"; they should be used with caution. 
prostitute themselves is above all financial, customers often invoke the prostitute's pleasure. Such an evocation situates sexual behavior generally considered selfish within an altruistic approach, aiming thereby to link it to traditional sexuality standards that presuppose seeking mutual pleasure. More generally, customers questioned say they are often sensitive to the "atmosphere" of the clubs they visit, particularly the role of glamour and seduction. In addition to physical pleasure, certain customers are looking for contact or a relationship. This quest to reproduce the classic forms of the love relationship (Brochier, 2005; Hoigard and Finstad, 1992) is also one of the motives cited for having recourse to border area prostitution: central and eastern European women are often described as warmer and less arrogant than western European women because "they have not yet been affected by the values of western female emancipation". (30) The role that sensuality and seduction in the clubs play in establishing the customer-prostitute relationship -a role that varies by club- reassures the customer about his ability to seduce and procure pleasure because it resituates the prostitutional relationship within the more general context of amorous and sexual relations between men and women. The prostitute is then described as an exceptional sexual partner, a "professional of pleasure" capable of reviving sexuality hitherto considered not very satisfying (Velten, 1994, p. 165). Certain customers acknowledge in these terms the prostitute's particular skills in the seduction and love game. A customer questioned at the Czech-Austrian border, for example, explained why he turned to prostitution despite being married: "The women are so hot here, you can just go at it!" It would seem, then, that in the prostitutional relationship, these men are actually looking for the possibility of leaving all initiative up to their partner, being "freed of the weight of being the one who always has to be stronger" (Mossuz-Lavau, 2005). The power relation operative in the prostitutional relation seems in this case more marked by that "uncertain quest" that customers are on (Howe, 2004) than by the often pregiven man-over-woman power position.

This representation of the prostituted woman as a "pleasure professional", together, of course, with the relatively low price of sexual services in the Czech Republic, also accounts for the motivations of young men in using prostitutional sexuality. Many Germans and Austrians between the ages of 18 and 25 go to border area prostitution clubs; those clubs therefore continue to function as places for initiating young men into sexuality. In this case, the roles of seduction and glamour are not as important as for older customers. Some clubs have even set up special services for young customers who "want things to go fast", (31) whereas older customers are more likely to say they choose women whom they could imagine being their girlfriends (Grenz, 2005) or to already have had a love relationship with a prostitute. The fantasy of establishing a love relationship with a prostitute-expert in the game of love is thus still very strongly anchored in customers' imaginations and attests to a quest for sentiment as well as sex.

(30) Words of a customer on the CzechAustrian border.
(31) Words of a prostitute working in clubs on the Czech-German border. 
The prostitutional relationship can therefore be understood as a vector for reaffirming the customer's virility, threatened by the omnipresence of increasingly violent sexual solicitations in the public space and the media, solicitations that posit "marital heterosexual sex [...] as the unique reference, not to be exceeded" (Mathieu, 1998) and by the dominant stigma that having recourse to the services of a prostitute is a sign that one cannot seduce women.

In this context, I see customers' attempts at heroicizing themselves as a way of responding to, and even resisting against, the stigma of being deviant (a loser or a pervert) associated with being a prostitution customer. The men I questioned, those who do not try to hide the fact that they have recourse to prostitutes, often emphasize the curiosity and adventurousness attested by their desire to "see what" a paying sexual relation "is like". Moreover, the adventurous dimension of using prostitutional sex is frequently accentuated by invoking the partially mythified risks involved in being in contact with the prostitution world, a world often described by the men I questioned as "dangerous". In this world, presented as if it were governed by criminal law alone, some customers related with pride the active role they played in "saving" a woman who had either been forced to be a prostitute or was a victim of sexual assault. These narratives, whose truth value is of little importance for this study, recall certain classical forms of heroic narration of chevalric inspiration which have lastingly influenced social representations of gender roles, namely the perception of certain behavior as virile. By citing the adventure and heroism motifs, customers put forward their male ability to save a woman, while posing as defenders of "ethical" prostitution. To do this, they obviously make use of a representation of the prostitute as forced to do the work she does, a representation that is theirs alone, and that leads them to deem whether or not it is necessary to rescue the women they encounter, depending on the degree to which they correspond to the necessarily stereotypical image these men have of a "victim".

The fact is that the images customers have of their prostitute sex partners in the border regions of western and southern Czech Republic have every appearance of being marked by the perception that the presence of eastern European women -but also European women in general- in Czech prostitution is a sign of their predisposition for market forms of sexuality. This stereotypical vision is strengthened and fueled by estimates of the increasing proportion of eastern European prostitutes on west European sex markets (Bruinsma and Meershoek, 1997) and by media enthusiasm for portraits of eastern European women prostituting themselves in the west. ${ }^{(32)}$ Most of the customers I interviewed insisted that the eastern European women practicing prostitution in clubs on the Czech border were doing so perfectly willingly and that their motives were purely financial. A sexual service consumer on the

(32) See the many articles on the "tragic destiny" of "Natachas", forced to prostitute themselves in western Europe; e.g., François
Loncle, 'L'Europe de l'Ouest, proxénète des femmes de l'Est", Le Monde Diplomatique, Nov. 2001 and Florian Klenk (see note 11). 
Czech-Austrian border stated, for example: "Eastern women are interested in money, that's why you find them in brothels the world over." Paradoxically, the same customers who had invoked the prostitute's pleasure and the sensual, glamorous dimension of the contact as factors motivating their use of crossborder prostitution stuck firmly to the argument that what led those women to prostitute themselves was the financial interest of the activity, as soon as I brought up the question of possible constraints on the women, particularly migrant ones. The choice of the prostitution "business" is thus understood to be due to the particular attraction that money-making has for certain women, namely eastern European ones. Customers' claim that the prostitute's motivations are material is generally expressed by means of much harsher, disenchanted discourse on the prostitute, because that belief shakes the fragile edifice of attempts to reinscribe prostitutional sexuality in the standards of the love relationship. As long as the financial aspect of the relationship is not mentioned, it seems that some customers seek to present contact with the prostitute as a case of classic seduction, where the partner's looks, his ability to seduce, and the general atmosphere of the encounter determine the outcome of the undertaking. On the contrary, as soon as the pecuniary aspect of the relationship is recalled, customers' discourse may quickly slip into accusing tones: the prostitutes' ostensibly material considerations run athwart the consumers' aspirations to a form of sexuality considered "normal". By choosing to sell their sexual services for a financial profit, women who prostitute themselves remind the customer of the impossibility of a disinterested love relationship and are therefore accused of being "no angels either" (33) and of "looking for" the potential troubles that may come with the practice of prostitution.

Analysis of prostitutional practices and discourses thus seems to reveal that customers have a generally negative perception of their own sexuality, and their attempts to justify behavior perceived as deviant attest not to any reference to a "deviant subculture" (Sykes and Matza, 1957) wherein recourse to prostitution would be presented as morally correct, but rather as an attempt to conform to the social norms in effect. Though prostitution customers in the border areas of the Czech Republic are different in many ways from the juvenile delinquents discussed by Sykes and Matza, their study of techniques for "neutralizing" the disapprobation inherent in the internalization of majority norms seems to shed light on some forms of discursive "clearing of themselves" used by prostitute customers. Customers' refusal to admit that they use prostitutional sexuality, even when it is quite obvious that they do, can be analyzed as a "denial of responsibility" technique aimed at breaking the tie between an individual and his acts, while customers' assertion that they are involved in a kind of "ethical" prostitution amounts to denying any correlation between an act and its possible consequences because it denies the possibility of "injuring" a third party (in this case, the prostitutes). Moreover, though I have not chosen an approach in terms of victims and victimizers, the

(33) Words of a customer interviewed on the Czech-Austrian border. 
neutralization strategy that consists in accusing prostitutes of being immorally motivated by a desire to make money can be likened to the "denial of the victim" that Sykes and Matza observed among delinquents. Customers are particularly likely to use this last type of rationalization in the case of migrant prostitutes: the fact that they migrated for the purpose of prostituting themselves is interpreted as a sign of their "guilt".

\section{Prostitutes: victims or accomplices?}

Does this mean that the migrant prostitute's statement that she migrated willingly to become a prostitute bothers people? Common sense tends to interpret migrating from east to west for prostitution purposes as an involuntary move made under constraint (Geisler, 2005; Schauer, 2006) and to present migrant prostitutes as "victims reduced to slavery, raped or kidnapped" (Pheterson, 2003), regardless of the real conditions of their migration move. Inversely, the victim's affirmation of her initial "consent" to exercise prostitution activities abroad is interpreted (including by customers, themselves victims of the stigma that brands the different actors in the prostitution world) as an admission of complicity because it is the sign of a power for taking sexual action (Butler, 1997). It therefore seems that sexual autonomy and the autonomy to migrate constitute the transgression (Pheterson, 2003), in the universal moral sense we conceive it; the transgression that leads people to think of prostitutes exclusively in terms of social mechanisms of control, stigmatization and submission (to customers, procurers, police officers, etc.). This is why it is important here, while never denying the reality of the physical and psychic threats that may weigh on women practicing prostitution, to render readable some of the power relations that run through prostitutional space.

As suggested by the remarks above about the sexual behavior of prostitution service customers, relations between customers and prostitutes are not always characterized by the "mechanical, impersonal chill generally described" but may on the contrary be inscribed in "certain forms of communication and exchange" (Brochier, 2005). These seem comparable to observations collected by Brochier in Rio de Janeiro clubs, and they indicate that prostitutes may have some maneuvering room in the exchange and negotiation of sexual services. First, contrary to the stereotype of the trafficking victim often applied to migrant prostitutes, it seems that most foreign women prostituting themselves on the Czech border think of selling sexual services to western European customers reputed to be wealthy as an economic strategy that will enable them to cope with a financial need. The move is thus very often made willingly (34) (though this of course does not preclude cases of trafficking in women or later appearance of forms of constraint), by women

(34) Interview with representatives of a health protection NGO working with prostitutes on the Czech-Bavarian border. 
who know the type of work that awaits them, even if they may have hoped for other working conditions (Š́́dová, 2004a). Many of the foreign women practicing in the border area clubs, most from the former socialist bloc, engage in prostitution to temporarily resolve a difficult economic situation, and they use various means of getting into prostitution. While most who arrive in the Czech Republic with the intention of working in the sex industry come with a three-month tourist visa, women who have come to practice in the sex business also use the asylum procedure and marriage to a Czech national (in some cases a German or Austrian) to legalize their stay. They generally contact the clubs through an intermediary who is in charge of obtaining the tourist visa and organizing their trip. These intermediaries -they are in fact procurers who sometimes also take on the role of boyfriend- have a network of club owner contacts in the Czech Republic to whom the women are then offered. After a migrant prostitute is hired to work in a club, the intermediary generally keeps his role of procurer and takes a percentage cut of the prostitute's earnings, as explained above. Contact with the club owner may also be established by the prostitute herself if she is already working in a place and is trying to get a friend or acquaintance hired too. Moreover, for many of the Ukrainian women, prostitution is part of a broader perspective of bringing a migrant workforce to the Czech Republic: certain women who initially came there to work in a factory or restaurant find that their wages hardly suffice to meet minimum needs and therefore decide that it is to their advantage to get into prostitution in clubs or in their apartment (Šídová, 2004b). Most women with a tourist visa go back to their native country after three months of activity to renew their visa, then return to the Czech Republic (or move further west). Some of the prostitutes working in the clubs have a residence permit, obtained after acquiring a business licence (which is very easy in the Czech Republic) and getting themselves registered as an "entrepreneur".

A significant proportion of women working in the clubs thus seem to think of this period of prostitution in the border area either as a transitory activity that will meet the needs of their families in their native countries or a stage in their career as prostitute, which they intend to pursue in other European cities where the sale of sexual services is financially more profitable. ${ }^{(35)}$ With this in mind, they often consider it normal to pay an intermediary to find them a place in a club. ${ }^{(36)}$ Likewise, as long as they are living in the club they do not seem to challenge the requirement that they pay a significant percentage of their takings to the club manager or even the fact that the manager exercises certain forms of verbal and psychological constraint on them; they consider this "part of the job" (37) (Hoigard and Finstad, 1992). The working conditions that outside observers filled with protective feelings are overquick to qualify as slavery may thus be considered in an entirely different light by the prostitutes themselves, for whom entering into prostitution seems to mean accepting the rules that govern the operation of that activity. Certain women

(35) See interviews with prostitutes on the Czech-German border.

(36) See information collected from Czech and German NGOs working to help prostitutes.

(37) Words of a prostitute on the CzechGerman border. 
identified as victims of trafficking in humans in the Czech Republic choose in spite of all to continue their occupational activity, knowing that on the Czech border they can earn enough money in a few months to live or study several years in Ukraine, for example. (38) Once again, I am not in the least calling into question prostitutes' overexposure to different types of violence; my point is simply that certain victimizing assumptions should not be allowed to hide the reality of the prostitution enterprise and how it may be perceived by the prostitutes themselves as a form of exchange between the parties involved: club manager, prostitute, and customer.

My observations of the terms of the exchange between customers and prostitutes in places of prostitution does not confirm the Manichean interpretation of dominating customers exploiting dominated prostitutes. On the contrary, it reveals that prostitutes use "certain means of controlling the unpleasantness of the activity" (Brochier, 2005). This control seems to me to involve "learning to internalize a stigma and how to manipulate it" (Pryen, 1999, p. 151). Up against the stigma that brands all prostitutes -perhaps especially migrant ones, who are more subject to police pressure and also more likely to be victims of rejection by other members of the prostitute community, who accuse them of helping to stigmatize the occupation ${ }^{(39)}$ - the distancing that prostitutes often practice with regard to some aspects of their activity and status may be analyzed as a form of learning to internalize and manipulate the stigma. In addition to the symbolic distance that the prostitution dress code is understood to establish between two statuses -"the paradigmatic figure of the 'whore' and themselves" (Welzer-Lang, Barbosa and Mathieu, 1994, p. 149)most of these women are visibly concerned to preserve a certain distance from the customer, as attested by some customer statements; e.g., the remark that "these girls are really gifted when it comes to hiding what they have to hide". ${ }^{40)}$ Speaking about this would amount to blurring the symbolic discontinuity between two identities, a discontinuity that gives the woman the feeling of preserving her integrity in the prostitution practice (Guillemaut, 2002, p. 50). Furthermore, establishing a distance between herself and the customer allows the prostitute to keep control of the situation in all circumstances. She "surrenders nothing of her private life; the point is to play a role to satisfy the customer's demand without investing oneself. This staging can be reproduced in all relations with customers, even if the point is sometimes to behave 'as if' the relationship were unique" (Pryen, 2002). The prostitutes I questioned often displayed contempt for customers who let themselves get taken in by the show; and they comment harshly and crudely on the men's sexual performance. The vocabulary used by prostitutes to speak of customers also works to establish this break between themselves and foreign sex tourists, sometimes designated "prasátka" (pigs), namely when they are being

(38) Interview with members of a health protection NGO working with prostitutes on the Czech-Bavarian border.

(39) Ukrainian women are generally accused by Czech and Slovak prostitutes of accepting degrading working conditions, namely the demand to practice unsafe sex.

(40) Words of a customer on the CzechGerman border. 
vilified for not following safe sex rules. ${ }^{(41)}$ The few Vietnamese customers are parti-cularly exposed to prostitutes' contempt. While the local population is generally quick to link the presence of a large Vietnamese community with the existence of many border area places of prostitution (see below), Vietnamese customers are unanimously rejected by the prostitutes I questioned, who say they are physically unattractive and poor sexual performers. Moreover, the interviews I conducted with prostitutes and my observations inside certain clubs go against the idea that these women have to accept all customers. Prostitutes usually say themselves that they are under no such obligation (except that they have to pay room rent at the end of the month), and though none of the customers I interviewed admitted having been turned away by a prostitute, the situations I observed in the clubs attest to this possibility. Some small clubs can give the outside observer and customer alike the feeling that they are disturbing the quiet of a family living room -women lying on the sofa in front of the television- and the rare customers who come on a weekday evening are often deemed of lesser interest than the latest video clips and therefore abandoned at the bar until they decide themselves to leave. These clubs are the favorite target of the bigger and more luxurious clubs' marketing operations; they stigmatize the lack of atmosphere in the small structures, saying they do not deserve to be called nightclubs. Without claiming that the "living-room" configuration is representative of border area nightclub prostitution, I do see this as a sign that prostitutional reality is highly diverse and much less monochromatic than the image one might have of it.

Furthermore, the prostitutes' ability to give the customers the feeling that each meeting is unique, and their publicly recognized aptitude for controlling male pleasure, seems to me an important vector for them of manipulating and reappropriating the stigma of the prostitute, a vector that enables them to resist, if only superficially, against "the unfavorable, resigned point of view" (Mathieu, 2000) that they tend to have of themselves. Staging their bodies (with clothes, the "costume", ${ }^{42)}$ exposure, etc.) as an instrument of male desire by suggesting "the sort of eroticism sought by the customer" (Gil, 2005 , p. 349) may indeed give the woman prostituting herself a feeling of power, even if it is only temporary. Independently of a certain resigned nostalgia in response to the fact that they have slipped into a stigmatized community (Goffman, 1963), the confrontation with women who do not come from the prostitutional community (in this case, the researcher) thus seems to stir in prostitutes a consciousness of their ability to incarnate a form of unconstrained relation to their body and sexuality that they can use to make their non-prostitute female interlocutors appear rigid and hampered by various sexual taboos. After asking about the researcher's professional and academic itinerary, a prostitute I interviewed outdoors at the village busstop first said

(41) Information collected from members of an NGO working with prostitutes on the Czech-Austrian border.

(42) I.e., the sense that Goffman (1967) gives to the term: "deportment, dress, and bearing, which serves to express to those in his immediate presence that he is a person of certain desirable or undesirable qualities". 
with a sad air that she was sorry to have "landed in prostitution" because she had preferred "partying" to study. However, a few moments later, she took off her clothes and pursued the interview in underwear in the middle of the public space, a move that may be interpreted as a means of letting her interlocutor know that she had access to different forms of freedom than the freedom assumed to be enjoyed by occupying a non-stigmatized social position. This of course may only have been apparent sexual liberation, a staging of sexual liberation by a woman whose body is above all an instrument of "economic accumulation" (Mathieu, 2000); and sexual liberation cannot be measured in terms of women's ability to expose and instrumentalize their bodies. Still, this theatrical way of using the body, aimed at making it appear not only the catalyst of male pleasure but also an incarnation of sexuality free of taboos, seems to me susceptible of being analyzed, together with the attempts at distancing mentioned above, as a form of resistance used by prostitutes to escape the pitying, miserabilist view people are likely to have of them.

The overvictimizing of prostitutes also leads to disregarding the discernment they are capable of using in the practice of their activities to avoid dangerous situations, potentially perverse customers and the health risks inherent in the sale of sexual services. The prostitutes I interviewed on the Czech-German border speak of customers with sado-masochistic tendencies and STDs as the main dangers of the prostitution activity, requiring permanent vigilance and a certain ability to decipher sexual service consumer behavioral patterns (Gil, 2005). Though most of the customers I met in the framework of this study deny this, there would seem to be many who say they will pay more for unprotected sex and who try to overcome the vigilance of prostitutes when they demand that they use a condom. ${ }^{(43)}$ The prostitutes also insist on the dangers that some customers' sexual fantasies put them in, and that they have to decipher so as not to engage in them. Having observed that older customers were particularly likely to exhibit sadomasochistic tendencies in their sexual relations, certain prostitutes said they protected themselves by systematically refusing to see customers over 60 . This claim, together with my observation of prostitution practices inside the clubs, attests to the possible existence of maneuvering room for prostitutes that allows them to turn away certain customers. Moreover, solidarity among prostitutes, generally described as declining in traditional places of prostitution (Mathieu, 2000), seems to exist at certain moments and in certain specific forms in the new prostitution regions comprised of the border spaces of the Czech Republic: prostitutes working in clubs on the Czech-German border, for example, explain that they systematically note the licence plate numbers of customers whom women leave with as escorts in order to notify the police if a colleague fails to return.

The comfort afforded by representing the prostitute as a victim and the customer as a pervert precludes opening up this closed-off zone of border area prostitution and analyzing the motivations that run through it, because it

(43) See statements by prostitutes and representatives of organizations working with them. 
allows observers to distance themselves from the emblematic figures that make them ill at ease and whom they are unconsciously concerned not to identify themselves with. Nonetheless, it seems to me that attempts to get beyond the stereotypical figures of customer and prostitute and the preconceptions that go along with them lead us to recognize the possibility that certain women decide to work in the sex industry as an alternative survival circuit (while keeping in mind that the aspects of prostitution practice observed here cannot claim to be the totality of prostitutional reality), and that the relation between prostitute and customer is not merely one of domination but may take the form of an exchange. However, in European debate ossified by the opposition between regulationists ${ }^{(44)}$ and abolitionists, ${ }^{(45)}$ the hypothesis that the parties implicated in the world of prostitution might be looking for "advantageous cooperation" (Brochier, 2005) with each other is generally accused of denying the reality of the violence experienced by prostituted women. But it has not at all been my intention to call into question prostitutes' overexposure to various forms of physical and psychological constraint; rather, to restore to each of the actors their place in sociology of the prostitution world.

\section{Border, deviance and stigmatization}

Due to the overrepresentation of foreign prostitutes and German-speaking customers in the border area prostitution world, that world is strongly perceived by local actors as a spot where foreign interests converge on the Czech Republic. In fact, a conception of the Other as morally and culturally different seems to crystallize around the border area sex market. Czech and east European women who engage in prostitution are generally perceived by the men I questioned as more available for paid sex than "western" women because they incarnate "a different attitude or relation to sex and money." (46) This perception, which I have had occasion to mention above, is based more or less implicitly on the notion of "civilization" (O'Connell Davidson, 2001), the idea being that the degree to which civilization is advanced is conditioned by the relation women have to exchanging the sexual act for money. The values of female emancipation are thought not to have reached eastern

(44) Regulationists see prostitution as an inevitable, even necessary social fact and advocate controlling it by subjecting it to certain rules (specific zones, maisons closes or eros-centers, police files or registers, medical surveillance of prostitutes, etc.). Instituted in France in 1802, this regime (called the French system) remained in place until 1946. It is supported in Europe by certain countries, often those of Germanic culture, namely the Netherlands, Germany, Austria and Switzerland; also
Greece and Turkey.

(45) The abolitionist position sees prostitution as a form of institutionalizing "male domination" that should be prevented and combated. France, Italy, Belgium and Great Britain officially support this position, though the abolitionist stance of some is occasionally tinged with regulationism.

(46) Words of a customer on the CzechAustrian border. 
European countries, ${ }^{(47)}$ and the "civilizational lag" is thought to be what explains these women's greater propensity to trade their sexual services. Because migrant prostitutes overtly incarnate this kind of relation in the eyes of the local population ${ }^{(48)}-i . e$. , sex that bothers people because it does not correspond to the image people tend to have of physical and psychic communion between two beings- and because they are foreigners for both their customers and the local population, they transgress a double boundary: that of traditional sex and that of national sovereignty (Berman, 2003).

The second figure of the Other in representations of the prostitutional space is the customer, who transgresses the same borders as migrant prostitutes -i.e., national and sexual ones- and is thus marked by the same stigma of moral and sexual deviance. For non-customers, the customer is a "loser" from the German or Austrian border regions who cannot claim to have a "normal" love life or sexual life and who therefore crosses the border to satisfy his more or less perverse desires in Czech clubs. Crossing the national border comes to seem a move invested with a power of sexual emancipation, or at least the promise of such (Donnan and Wilson, 1999, p. 91), that allows for realizing types of sexuality considered impossible in the native country.

But this moral, sexual, even possibly criminal stigma surrounding customers and prostitutes also seems to apply to other figures of the Other in the Czech landscape, figures who, while not directly my subject, are implicated in the social representation of the border region as governed by outside interests. First, the overexposure of Romani prostitutes in street prostitution, (49) and the perception that the local population has of them as immoral and linked to various criminal networks have potentially influenced certain representations of border area prostitution in clubs and on the street. The image of Romani women of little virtue put on the street to work by violent, criminal husbands, brothers or fathers seems to have induced the local population to lump together Roma and prostitution, ${ }^{(50)}$ and prostitution and criminality, and this moves people to perceive prostitutes as foreigners and persons who fall outside the realm of dominant moral values. ${ }^{(51)}$ Second, the presence of a large Vietnamese community, established in the border areas of the Czech Republic since the fall of the communist regime and the opening of the borders, may have facilitated certain associations between "foreigner" and "disorder" in the local imagination, despite the fact that that community is not directly involved in the prostitution world. The Vietnamese, who first came to Czechoslovakia and the GDR in the 1960s on job contracts made between

(47) Statements collected from customers on the Czech-Austrian border.

(48) Like migrant prostitutes originally from the former socialist states, Czech prostitutes are not generally from the regions they practice in, and Romani women prostituting themselves on the street are perceived as foreigners and accused of immorality.

(49) Most of the prostitutes on border area highways are Roma.
(50) A perception facilitated by media coverage of anti-procurer police operations aimed at Romani procurers; $c f$. the national police's "organized crime repression" unit capture of a group of traffickers described as one of the biggest in the Czech Republic; the main members of the group were Roma.

(51) However, most Romani prostitutes in the border regions are of Czech nationality; the others are Slovakian. 
those countries and the socialist republic of Vietnam, began settling in the border areas of the Czech Republic in the early 1990s after the political changes in the former socialist states had invalidated the agreements that had sent them to work in Czechoslovakian and East German factories. They set up in business selling Asian-produced goods, developing the huge "bazaars" mentioned above on the Czech-German and Czech-Austrian borders, bazaars specialized in counterfeit merchandise, cigarettes and garden gnomes. Though there is no pre-established tie between the sex markets and the activities of the Vietnamese community, that community is often immediately mentioned by Czech residents and German-speaking prostitution customers and tourists questioned about border area prostitution. This unfounded link in people's minds may be accounted for by the fact that the existence of the Vietnamese markets, like that of the prostitution clubs, is based on a strong economic differential between the Czech Republic and its "west-European" neighbors. In addition to the image of a closed, non-integrated community associated with the Vietnamese population settled in the Czech Republic (Hurrle, 2006) and that seems to have worked to get them perceived as secretive and potentially criminal, (52) the Vietnamese living in border areas (and the same is true for the prostitution clubs) are often said to have marred the image of these regions with their immense open-air markets, considered ugly, and a kind of unglamorous "discount" tourism.

Vietnamese and Roma thus seem to find themselves at the intersection of two types of stigmatization, the same that mark customers and prostitutes; stigmatization that combines racist stereotypes and moral judgments and that sees foreigners as a factor perverting the image and mores of the region and as agents serving criminal networks that profit from unmentionable activities. Citizens' initiatives have been launched in certain Czech border towns to "provide solutions to the problems of prostitution, the Vietnamese and the Roma", attesting to the intertwining of these three phenomena in the collective imagination of the border populations. (53)

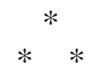

Because it is located "on the edges" and because the majority of actors involved in or commonly associated, rightly or wrongly, with prostitution activities are foreign, border area prostitution can be seen as the archetype of a separate space, a border zone "cut off from the outside" (Brochier, 2005). The high concentration of businesses selling sexual services in the border regions of the Czech Republic is generally perceived by the local populations as resulting from the encounter between types of foreign immorality on the

(52) Representation confirmed in interviews with inhabitants of Czech Republic border areas.

(53) See Rendlová, 2004, "Das Bild des deutsch-tschechischen Grenzraums in der tschecheschen Zeitung 'Chebsky denik' im letzten Quartal 2003”, Faculty of Philosophy of the Technical University of Chemnitz. 
border. The border space sex markets are also seen in a way as "the price to pay" for the opening of the Czech borders, inducing perception of the proximity of the German and Austrian borders as simultaneously "one of the main advantages [...] and one of the greatest weaknesses" of the Czech border areas. ${ }^{(54)}$ The corollary of this representation is that the prostitutional hyperactivity on the border has become relatively taboo; ${ }^{(55)}$ its very existence is experienced as calling into question the image of social progress usually associated with the end of communism. In this understanding, the Czech Republic, in exchange for its "return to Europe", should have accepted, or rather feigned ignorance of, the fact that the northern, western and southern borders were being transformed into immense sex markets for European tourists (namely Germans and Austrians). Despite initiatives by Czech border towns to regulate prostitution, ${ }^{(56)}$ local people's view of the sex business in their area seems in a way to be undergoing "normalization". The visibility of prostitutes in public spaces, and the fact that they often go to the same cafés and shops as the locals -locals who, when interviewed personally, usually say they have good relations with these women- suggest that the population may becoming to see the practice of prostitutional sexuality as normal. Of course, as I have shown, the massive installation of prostitution businesses is accused of tarnishing the image of the border regions, and the prostitutes are actively party to this, but the individual relations between inhabitants and women working in the sex business actually seem, despite all, at least somewhat free of certain forms of stigmatization. People hail these women in the street, ask after their health, and a married, retired watercolorist living in a house surrounded on both sides by prostitution clubs says he sometimes takes prostitutes as models for his portraits. Moreover, in the last few years the number of Czech men in these establishments has increased. For an increasing number of young Czechs living in the border regions, the clubs are becoming places to go to at night in the same way as "classic" bars, without their being necessarily associated with sexual service consumption. ${ }^{(57)}$ Generally, and though it remains stigmatized, the prostitutional activity seems to enjoy greater moral "acceptability" in the Czech border zones than in Germany or Austria, even though prostitution is a recognized occupation in those countries. The development of prostitution as an "acceptable" social fact in the former socialist states has often been presented as resulting from the fall of the communist regimes and national independence, both of which are understood to have favored the appearance of a "pornographic icon" (Watson, 1993) as the new symbol of freedom. Repressed under the communist regime, prostitution and

(54) Words of the mayor of Cheb, a city on Czech-German border; quoted in Hurrle (2006, p. 21).

(55) See for example the short film "České Velenice Infinity" included in the documentary film Across the Border: Five views of neighbors, by Pawel Loziński, Jan Gogola, Peter Kerekes, Robert Lakatos and Biljana Čakič-Veselič, Austria 2004.

(56) Representatives of 25 towns adopted a declaration in August 2000 calling on the government and parliament to take action against prostitution in the border regions. Some border towns have also launched their own initiatives; e.g., the town of Ars, which in February 2006 introduced billboards indicating the areas prostitution is permitted in and those in which it is prohibited.

(57) Czech men questioned on leaving a club on the Czech-German border. 
recognition of it as a social phenomenon may well have appeared as signs of sexual liberation in the 1990s. Moreover, the economic and political context of the 1990s, marked by the reduced presence of women on the job market and by the increase in individual freedom and the opening of the countries' borders, may have helped make the prostitution associated with certain "marginal" territories, particularly the border regions, "ordinary". The prostitutes thus seem in reality to enjoy tolerance, possibly motivated by certain economic considerations on the place of women on the job market, particularly migrant women. This stands in contrast to the attitudes of most of the German and Austrian men I interviewed in Czech border regions, who vehemently declared that it would be "unthinkable" for prostitution clubs to become likewise integrated into the German or Austrian landscape. Should we see the downplaying of the sex trade on the Czech side as the sign of gradual slippage of the terms implicated in a "moral division of labor" (Hughes, 1993) in the border areas, resulting from both an awareness of the economic constraints weighing on the women who prostitute themselves and the presence of a considerable reservoir of directly accessible potential customers? In this understanding, the border, because crossable, is both an institution that makes possible border area prostitutional sexuality and an instrument for reaffirming a dividing line between the acceptable and the unacceptable, by means of a process of distributing the different moral functions (ibid.) between the nations on either side of the border. Though open, the border thus maintains some of its former materiality for the west-European neighbors, allowing the "dirty work", which goes counter to the more heroic of "our moral conceptions" (ibid., p. 343) to be relegated to the other side of the national dividing line -the Czech Republic in this case. The act of moving the acceptable to the edges of the national territory would then also be what distinguishes the confined space of border prostitution from prostitutional sexuality in the rest of the Czech territory. Because of its situation "on the margin", border area prostitution could thereby offer a particularly fitting field for understanding the affective and fantasy-related power vested in places of prostitution (Botelho de Mattos and Angelo Campos Ribeiro, 1997) and their role in individual and collective representations.

Mathilde DARLEY

Institut d'Études Politiques, Paris

Centre Marc Bloch

Schiffbauerdamm 19

10117 Berlin - Germany

mathilde.darley@cmb.hu-berlin.de

Translation: Amy Jacobs

Previously published: RFS, 2007, 48, 2 


\section{REFERENCES}

Berman J., 2003. - "(Un)Popular Strangers and Crises (Un)Bounded: Discourses of Sex-Trafficking, the European Political Community and the Panicked State of the Modern State", European Journal of International Relations, 9, 1, pp. 37-86.

Bishop R., Robinson S. L., 1998. - Night Market: Sexual Cultures and the Thai Economic Miracle, London, Routledge.

Botelho de Mattos R., Angelo Campos Ribeiro M., 1997. - "Les territoires de la prostitution dans les espaces publics de la zone centrale de Rio de Janeiro", Géographie et Cultures, 24, pp. 9-28.

Bouamama S., 2004. - L'homme en question. Le processus du devenir-client de la prostitution, IFAR, Mouvement du Nid: http://www.mouvementdunid.org/IMG/pdf/HommeEnQuestion.pdf.

Brochier C., 2005. - "Le travail des prostituées à Rio de Janeiro", Revue Française de Sociologie, 46, 1, pp. 75-113.

Bruinsma G. J. N., Meershoek G., 1997. - "Organized Crime and Trafficking in Women From Eastern Europe in the Netherlands", Transnational Organized Crime, 3, 4, pp. 105-119.

Butler J., 1997. - Excitable Speech: A Politics of the Performative, New York, Routledge.

Corbin A., 1978. - Les filles de noce. Misère sexuelle et prostitution aux $19^{e}$ et $20^{e}$ siècles, Paris, Éditions Aubier Montaigne.

Donnan H., Wilson T. M., 1999. - Borders. Frontiers of Identity, Nation and State, Oxford, Berg.

Geisler A., 2005. - Gehandelte Frauen. Menschenhandel zum Zweck der Prostitution mit Frauen aus Osteuropa, Berlin, Trafo-Verlag.

Gil F., 2005. - "Sexualité et prostitution” in M.-É. Handman, J. Mossuz-Lavau (eds.), La prostitution à Paris, Paris, Éditions de la Martinière, pp. 345-376.

Goffman E., 1963. - Stigma: Notes on the Management of Spoiled Identity, Englewood Cliffs, Prentice-Hall.

- 1967. - Interaction Ritual: Essays in face-to-face Behavior, Chicago, Aldine.

Grenz S., 2005. - "Sex Tourism and Trafficking. The Perspective of Male Heterosexual Clients of Prostitutes", Conference Women's World 05, Seoul (Korea), University Ewha, June.

Guillemaut F., 2002. - Femmes et migrations. Les femmes venant d'Europe de l'Est, Lyon, Éditions Cabiria.

Hoigard C., Finstad L., 1992. - Backstreets, Prostitution, Money and Love, Cambridge, Polity Press.

Howe Ch., 2004. - "Ergebnisse der qualitativen Studie über Kunden von ausländischen Prostituierten", Acts of Symposium Prostitutionskunden. Sich austauschen, um Standpunkte zu verrücken, context e.V., pp. 31-45.

- 2006. - "Bilderwelten-Innenwelten. Prostitution und das Verhältnis der Geschlechter", Osteuropa, 6, pp. 67-85.

Hughes E. C., 1993. - The Sociological Eye: Selected Papers, London, Transactions.

Hurrle J., 2006. - "Město a tržiště", Kulturní Týdeník, 10, p. 21.

Månsson S.-A., 2006. - "Men’s Demand for Prostitutes", Sexologies, 15, 2, pp. 87-92.

Mathieu L., 1998. - "Le fantasme de la prostituée dans le désir masculin", Panoramiques, 34, pp. 72-79.

- 2000. - "L'espace de la prostitution. Éléments empiriques et perspectives en sociologie de la déviance", Sociétés Contemporaines, 38, pp. 99-116.

Mossuz-Lavau J., 2005. - "Qui sont les clients?” in M.-É. Handman, J. Mossuz-Lavau (eds.), La prostitution à Paris, Paris, Éditions de la Martinière, pp. 295-322.

O'Connell Davidson J., 2001. - "The Sex Tourist, the Expatriate, his Ex-Wife and her 'Other': the Politics of Loss, Difference and Desire", Sexualities, 4, 1, pp. 5-24.

Pheterson G., 2003. - “Grossesse et prostitution. Les femmes sous la tutelle de 1'État”, Raisons Politiques, 11, pp. 97-116. 


\section{Revue française de sociologie}

Prieur A., Taksdal A., 1993. - "Clients of Prostitutes. Sick Deviants or Ordinary Men? A Discussion of the Male Role Concept and Cultural Changes in Masculinity", NORA, 2, pp. 105114.

Pryen S., 1999. - Stigmate et métier. Une approche sociologique de la prostitution de rue, Rennes, Presses Universitaires de Rennes.

— 2002. - "Prostitution de rue: le privé des femmes publiques", Ethnologie Française, 1, pp. 11-18.

Redoutey E., 2005. - "Trottoirs et territoires, les lieux de la prostitution à Paris" in M.-É. Handman, J. Mossuz-Lavau (eds.), La prostitution à Paris, Paris, Éditions de la Martinière, pp. 39-89.

Schauer C., 2003. - Kinder auf dem Strich. Bericht von der deutsch-tschechischen Grenze, Bad Honnef, UNICEF/ECPAT, Horlemann Verlag.

- 2006. - "Jeder holt sich, was er will. Sexuelle Ausbeutung von Frauen und Kindern in einer tschechischen Grenzregion", Osteuropa, 6, pp. 235-244.

Šídová L., 2004a. - “Organizace bulharské prostituce v České republice”, Migrace Online, Multikulturní Centrum Praha: http://www.migraceonline.cz/e-knihovna/?x=1955310.

— 2004b. - "Ukrajinská prostituce v České republice a způsob její organizace", Migrace Online, Multikulturní Centrum Praha: http://aa.ecn.cz/img_upload/9e9f2072be82f3d69e3265f41fe9f28e/Ukrajinskeprostitutky.pdf

Siegmund J., 2006. - "Die unbekannte Spezies. Ein Versuch, sich dem Phänomen Freier zu nähern", Osteuropa, 6, pp. 87-98.

Sykes G. M., Matza D., 1957. - "Techniques of Neutralization: A Theory of Delinquency", American Sociological Review, 6, pp. 664-670.

Velten D., 1994. - Aspekte der sexuellen Sozialisation. Eine Analyse qualitativer Daten zu biographischen Entwicklungsmustern von Prostitutionskunden, Inauguraldissertation, Berlin, Freie Universität Berlin.

Watson P., 1993. - "Eastern Europe's Silent Revolution: Gender", Sociology, 27, 3, pp. 471-487.

Welzer-Lang D., Barbosa O., Mathieu L., 1994. - Prostitution: les uns, les unes et les autres, Paris, Éditions Métailié. 